\title{
Fungal pathogens associated with crown and collar rot of apple trees in southern Syria
}

\author{
Abeer RASHID ${ }^{1}$, Walid NAFFAA ${ }^{2 *}$ \\ Received April 08, 2016; accepted Janury 12, 2017. \\ Delo je prispelo 08. aprila 2016, sprejeto 12. januarja 2017.
}

\begin{abstract}
Crown and collar rot of apple trees is a destructive and widespread disease in most areas of the world. Surveys have been done to describe disease symptoms, estimate the disease incidence, and identify the pathogens associated with this disease in southern Syria. Disease incidence was $0.08-10 \%$ in most studied sites, only in Alroom location it was up to $14.7 \%$ in 2014 and $17.8 \%$ in 2015, with average of $11.8 \%$. Symptoms included small pale green leaves, sparse foliage, and a reddish-brown discoloration of inner bark of the infected area at the base of infected tree. The isolated fungi belonged to genera and form genera Phytophthora, Rosellinia, Rhizoctonia, Phialophora, Acremonium, Pestalotiopsis, Cylindrocarpon and Verticillium. Phytophthora was isolated from all infected trees, and was the most frequent pathogen (53.7\% of total isolates). Phytophthora isolates recovered from crown cankers of apple were identified as $P$. cactorum $(91.5 \%)$ and $P$. cambivora $(8.5 \%)$. The results of this study are the first report of crown and collar root rot of apple in Syria.
\end{abstract}

Key words: crown and collar rot; apple tree; associated fungi;, Phytophthora; Syria

\section{IZVLEČEK}

\section{GLIVNI PATOGENI, POVEZANI Z ODMIRANJEM KROŠNJE IN GNILOBO KORENINSKEGA VRATU JABLANE V JUŽNI SIRIJI}

Odmiranje krošnje in gniloba koreninskega vratu jablane je uničujoča in široko razširjena bolezen na večini njenih pridelovalnih območij. Na območju južne Sirije so bile opravljene raziskave za opis bolezenskih znakov, pogostosti pojavljanja bolezni in prepoznavanja njenih povzročiteljev. $\mathrm{Na}$ večini raziskanih mest se je bolezen pojavljala z 0,08 do $10 \%$, samo na lokaciji Alroom pa do $14,7 \%$ v letu 2014 in do $17,8 \%$ v letu 2015 , povprečno $11,8 \%$. Bolezenski znaki so bili majhni bledo zeleni listi, redka olistanost in rdeče-rjavo obarvano ličje okuženih delov na bazi debel dreves. Izolati gliv so pripadali naslednjim rodovom gliv: Phytophthora, Rosellinia, Rhizoctonia, Phialophora, Acremonium, Pestalotiopsis, Cylindrocarpon in Verticillium. Glive iz rodu Phytophthora so bile najpogostejši pathogen in izolirane iz vseh okuženih dreves, 53,7\% vseh izolatov. Izolati vrst iz rodu Phytophthora, ki so se razvili iz rakov v krošnji jablan, so bili določeni kot vrsti $P$. cactorum $(91,5 \%)$ in $P$. cambivora $(8,5 \%)$. Izsledki te raziskave so prvi o pojavljanju bolezni odmiranja krošenj in gnilobe koreninskega vratu jablane v Siriji.

Ključne besede: odmiranje krošnje; gniloba koreninskega vratu; jablana; $\mathrm{z}$ boleznijo povezane glive; Phytophthora; Syria

\section{INTRODUCTION}

Crown rot is an important soil-borne disease of apple Malus domestica Borkh. and pear trees Pyrus communis L. in most production regions of the world (Jeffers and Wilcox, 1990; Thomidis et al., 2002). Symptoms generally include: reduced tree vigor and growth, yellowing or chlorosis of leaves and eventual collapse or death of the tree (Nakova, 2010). Crown rots and trees declining and dying are frequently misdiagnosed as suffering from root asphyxiation, and sometimes confused with those suffering from winter injury (Ellis, 2008). Crown rot advances rapidly and trees collapse after the

1 Directorate of Agriculture and Agricultural Reform, Sweida, Syria

2 Damascus University, Faculty of Agriculture, Plant Protection Dept., 30621 Damascus, Syria, *corresponding author: walid1851966@yahoo.com 
first warm weather in spring (Teviotdale and Gubler, 1999).

Several Phytophthora spp. are known to cause crown, collar and root rots of apple trees in most areas of the world where this crop is grown (Erwin and Ribeiro, 1996; Jeffers and Wilcox, 1990; Judelson and Blanco, 2005; Brasier, 2008). Ph. cactorum (Lebert \& Cohn) J. Schröt. has been the species most frequently associated with crown and root rot of apple throughout much of the world, but other species of Phytophthora have been associated with crown rot of apple or pears trees such as Ph. cambivora (Petri) Buisman., $P$. citricola Sawada, $P$. cryptogea Pethybr. \& Laff., $P$. drechsleri Tucker, P. megasperma Drechsler,, $P$. parasitica Dastur, Pseudomonas syringae Van Hall, 1904, and several unidentified Phytophthora spp. (Jeffers et al., 1981; Jeffers and Aldwinckle,
1986, 1988; Browne et al., 1995; Thomidis et al., 2002). Crown rot incidence was highly variable, depending on rootstock, pathogen, and flooding duration (Wilcox, 1993). Ellis (2008) states that wet soils that remain saturated for extended periods are required for disease development. Periods of $24 \mathrm{~h}$ or more of saturated soil favor Phytophthora infections. Conversely, good soil drainage and more frequent but shorter irrigation reduce the risk of root and crown rot (Teviotdale and Gubler, 1999).

In Syria, no previous studies have been conducted on decline and death of apple trees. The purpose of this study was to discover disease symptoms, to evaluate the incidence of this disease, and to identify the fungi associated with crown rot of apple trees in southern Syria where apples and pears are grown.

\section{MATERIALS AND METHODS}

\subsection{Surveying and sampling}

The survey was conducted from January 2014 to May 2015 in apple orchards distributed in eight different locations in Daher Aljabal region where apples are grown in the province of Swaida in southern Syria. Percentage of infected orchards at each site, and the percentage of infected trees in each orchard was estimated, then the disease incidence in each site was calculated.

A hundred and forty nine samples of infected plant materials (stem base) were collected from 35 different orchards of approximately 408 acres.

\subsection{Fungal Isolation}

Necrotic crown tissues were removed from diseased apple trees, thoroughly washed with running water, surface sterilized with $70 \%$ ethanol for 30 seconds, washed with sterile distilled water, dipped in $6 \%$ sodium hypochlorite for 5 minutes, washed twice with sterile distilled water, dried on a sterilized filter paper, and cut into small pieces $(2 \mathrm{X}$ $5 \mathrm{~mm})$. They were then plated into Petri dishes with two media: potato dextrose agar PDA (39 g/l) and cornmeal agar CMA (30 g/l cornmeal and $20 \mathrm{~g} / \mathrm{l}$ agar in 11 of sterile water) both supplemented with antibiotic (Amoxicillin $100 \mathrm{ppm}$ ). Petri dishes were incubated in darkness at $21^{\circ} \mathrm{C} \pm 2$ for 7 days. Pure cultures were made by additional transfers (several sub-culture). Fungal isolates were identified based on their morphology according to International Mycological Institute (I.M.I.) Descriptions of Pathogenic Fungi and Bacteria (Minter and Cannon 2015).

\section{RESULTS AND DISCUSSION}

\subsection{Incidence and distribution of apple crown rot}

Incidence of the disease varied significantly depending on the location and on the orchards within the same site. The percentage of orchards where the disease was observed ranged from $0 \%$ to $100 \%$. The disease incidence was $0.08-17.8 \%$, and the average of the disease incidence was $11.8 \%$ in Daher Aljabal region (Table 1). 
Table 1: Incidence of crown and collar rot disease of apple trees in southern Syria

\begin{tabular}{|l|c|c|c|c|c|}
\hline \multirow{2}{*}{ Site } & Date & $\begin{array}{c}\text { Number of } \\
\text { Orchards }\end{array}$ & $\begin{array}{c}\text { Area of studied } \\
\text { orchards (hectares) }\end{array}$ & $\begin{array}{c}\text { Percentage (\%) } \\
\text { of infected } \\
\text { orchards }\end{array}$ & $\begin{array}{c}\text { Disease } \\
\text { incidence } \\
(\%)\end{array}$ \\
\hline Ayon Alsoufer & $30 / 01 / 2014$ & 5 & 6.3 & 80 & 2.5 \\
\hline Albassaa & $09 / 02 / 2014$ & 7 & 9.6 & 71.42 & 9.6 \\
\hline Alshoaf Algharbi & $05 / 06 / 2014$ & 5 & 11.5 & 20 & 0.08 \\
\hline Almazlaghat & $11 / 08 / 2014$ & 10 & 6.8 & 10 & 0.1 \\
\hline Almouaker & $11 / 08 / 2014$ & 2 & 2.0 & 100 & 10 \\
\hline Alroom & $11 / 08 / 2014$ & 4 & 3.0 & 100 & 14.7 \\
\cline { 2 - 6 } & $03 / 5 / 2015$ & 4 & 3.0 & 100 & 17.8 \\
\hline Aljeemah & $08 / 09 / 2014$ & 1 & 1.2 & 100 & 0.8 \\
\hline Kanawat & $09 / 09 / 2014$ & 1 & 0.4 & 0 & 0 \\
\hline & $\mathbf{2 0 1 4}$ & $\mathbf{3 5}$ & $\mathbf{4 3 . 8}$ & $\mathbf{4 7 . 5 2}$ & $\mathbf{1 1 . 8}$ \\
\hline
\end{tabular}

Disease incidence ranged from $0.08 \%$ to $10 \%$ in most studied sites, only in Alroom location it was $14.7 \%$ in 2014 and $17.8 \%$ in 2015. This high percentage of infected trees was more often observed in lowland areas of the orchards, especially when soils are clay, heavy and poorly drained. In fact, similar results have been reported in some previous studies (Wilcox, 1998; Hickey and Yoder, 2001). Nakova (2010) showed that crown rot spread was $2-3 \%$ in most gardens, and only in an apple orchard in Bjaga (Plovdiv region) it was up to $8-10 \%$ and also pointed out that disease spread is favored by wet, heavy and poorly-drained soils, and heavy rains also provoke disease symptoms.

\subsection{Symptoms of apple crown rot}

The trees infected by crown and collar rots showed symptoms including bud break delay in early spring, the presence of small pale green leaves, sparse foliage and the absence of vigorous growth of terminal shoots. In late spring, leaves of infected trees show reddish discoloration and drop down. Twigs and branches dieback. Infected trees may decline slowly, or they may die suddenly in the latter part of the growing season.

A reddish-brown discoloration of inner bark can be seen by removing the outer bark layer of the infected area at the base of infected tree several centimeters above the ground surface (Fig.1). These symptoms were reported in many previous studies of Phytophthora root and crown rot (Ellis, 2008; Nakova, 2003, 2010). We also noted that trees showing symptoms of crown rot disease were more sensitive to be infected by bacterial canker and papery bark disease caused by Pseudomonas syringae pv. syringae. Approximately $30 \%$ of the trees infected by crown rot disease were also infected later by bacterial canker. 

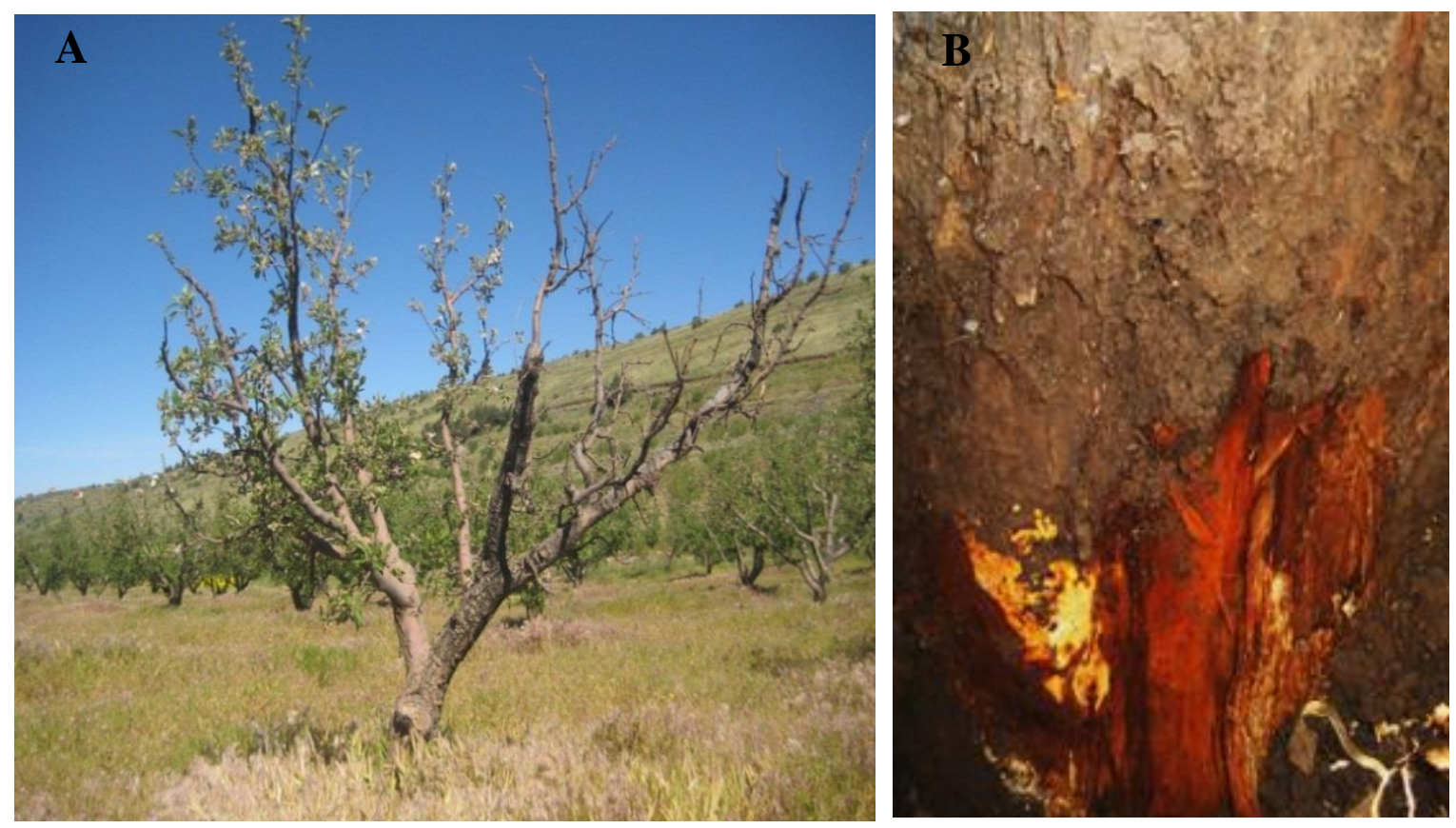

Figure 1: (A) Infected tree showing sparse small chlorotic leaves, die back of branches. The tree was later infected by bacterial canker. (B) A reddish-brown discoloration of inner bark of the infected area at the base of infected tree.

\subsection{Fungi associated with crown rot of apple trees}

Two hundred sixty isolates were obtained from crown cankers of apple trees. A hundred seventy five were identified according to their morphology. The isolated fungi belonged to genera and form genera such as Phytophthora, Rosellinia, Rhizoctonia, Phialophora, Acremonium, Pestalotiopsis, Cylindrocarpon and Verticillium. However, the relative dominance of individual species in the fungal community isolated from apple varied among the orchards, and some fungi of this complex were absent in specific orchards. Phytophthora was isolated from all infected trees, and dominated the fungal population $(53.7 \%$ of total isolates) recovered from crown cankers of apple. According to their morphology, $91.5 \%$ of Phytophthora isolates were identified as $P$. cactorum, and $8.5 \%$ as $P$. cambivora.

Colonies of $P$. cactorum were whitish, fluffy or smooth on PDA. Zoosporangia were oval to elongated (lemon shape) with papillae. Terminal or intercalary chlamydospores were found. Antheridia and oogonia, as well oospores, were formed in large numbers (Fig. 2). Colonies of $P$. cambivora were whitish, fluffy with dense aerial hypha. Zoosporangia were nonpapillate, ellipsoid or ovoid. Chlamydospores were absent. 

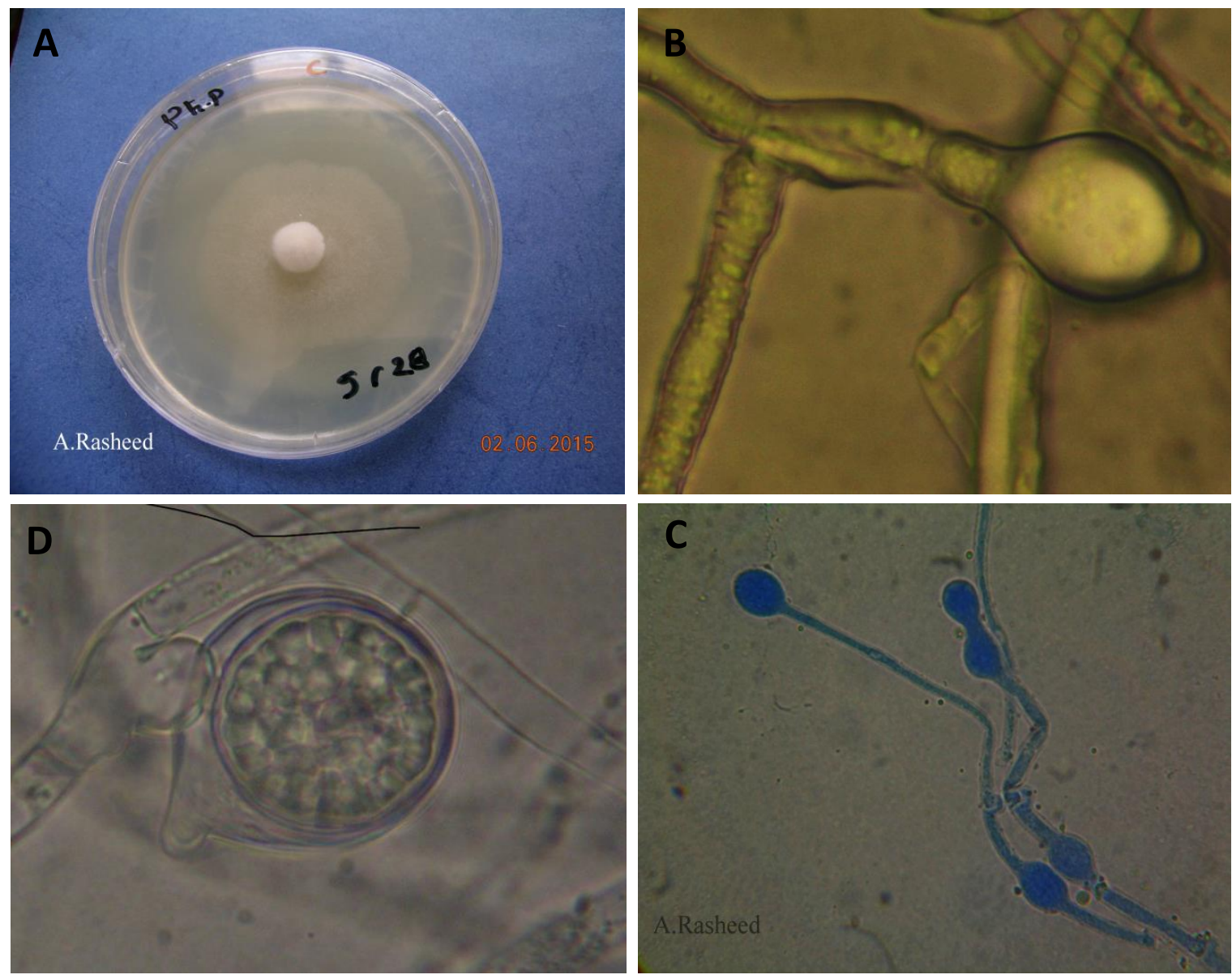

Figure 2: (A) colony of $P$. cactorum on PDA. (B) Limon shape sporangium with papillae. (C) Terminal and intercalary chlamydospores. (D) Sexual organs (antheridium and oogonium).

The morphology of sporangia, and general morphology of isolates of the two identified Phytophthora species were similar to those described in many studies (Waterhouse, 1963, 1970; Nakova, 2010; Welsh, 2011). Matheron et al. (1988) showed that $P$. cactorum and $P$. cambivora were highly virulent and caused rapid decline and death of apple seedlings, and these pathogens also were the most frequently isolated Phytophthora spp. in commercial apple orchards in Arizona.

The frequency of other fungi associated with crown and collar rot of apple trees varied from $1.7 \%$ for Verticillium sp. to 18.3 for Rhizoctonia solani J.G. Kühn (Table 2).
This study showed that $P$. cactorum was the most important fungal species causing crown and collar rot of apple in Swaida where the apple trees are grown in southern Syria. In fact, $P$. cactorum has been the species most frequently associated with crown and root rot of apple throughout much of the world (Jeffers et al. 1981; Jeffers and Aldwinckle, 1986, 1988; Browne et al. 1995; Thomidis et al., 2002). Isolation of $P$. cactorum has been possible only from the margins of active lesions. There is evidence that the activity of $P$. cactorum is inhibited in rotted tissues by the antagonistic effect of one or more secondary organisms. These results are in according to those of Welsh (2011). 
Table 2: Percentage of fungi associated with crown and collar rot of apple

\begin{tabular}{|l|c|c|c|c|c|c|c|c|}
\hline Fungi & Ro & Rh & Ph & Phi & Ac & P & C & V \\
\hline Number of isolates & 11 & 32 & 94 & 13 & 10 & 5 & 7 & 3 \\
\hline Percentage \% & 6.3 & 18.3 & 53.7 & 7.4 & 5.7 & 2.9 & 4 & 1.7 \\
\hline
\end{tabular}

Ro: Rosellinia, Rh: Rhizoctonia sp., Ph: Phytophthora sp., Phi: Phialophora sp., Ac: Acremonium sp., P: Pestalotiopsis sp., C: Cylindrocarpon sp., V: Verticillium sp.

In addition to Phytophthora spp., a fungal complex consisting of Rosellinia sp. (6.3\%), Rhizoctonia solani (18.3\%), Phialophora sp. (7.4\%), Acremonium sp. (5.7\%), Pesalotiopsis sp. (2.9\%), Cylindrocarpon sp. (4\%) and Verticillium sp. $(1.7 \%)$, was associated with crown and collar rot of apple. Many studies conducted in Washington State indicated that a fungal pathogen complex, consisting of Nectria radicicola Gerlach \& L. Nilsson (Cylindrocarpon destructans (Zinssm.) Scholten), Phytophthora cactorum, Pythium spp., and Rhizoctonia solani was the predominant cause of replant disease of apple trees, and were consistently isolated from symptomatic trees in all orchards, and these fungi were pathogenic to apple in greenhouse tests (Mazzola, 1998; Mazzola et al., 2001; Braun, 1995). Pestalotiopsis spp. have been reported to cause root and crown rot of strawberry in Spain (Chamorro et al., 2016), canker and twig dieback of blueberry in Chile (Espinoza et al., 2008), black foot of grapevine in Portugal (Oliveira et al., 1998). In fact, the soilborne fungus Rosellinia necatrix Berl. ex Prill., is the causal agent of white root rot disease on numerous plant species, including apple (Pasini et al., 2016).

\section{CONCLUSIONS}

Crown rot of apple in Swaida in the south of Syria is associated with many fungi, but the main cause of this disease, and the most frequently isolated pathogen is $P$. cactorum. The result of this study is the first report of crown rot of apple trees in Syria.

\section{REFERENCES}

Brasier, C. (2008). Phytophthora biodiversity: How many Phytophthora species are there? Workshop on Phytophthoras in Forest and Natural Proceedings 4th IUFRO Ecosystems, Working party S07.02.09, Monterey, California, USA, pp. 101-115.

Braun, P. G. (1995). Effects of Cylindrocarpon and Pythium species on apple seedlings and potential role in apple replant disease. Can. J. Plant Pathol. 17:336-341. doi:10.1080/07060669509500672

Chamorro, M., Aguado, A. \& Berta De los Santos. (2016). First Report of Root and Crown Rot Caused by Pestalotiopsis clavispora (Neopestalotiopsis clavispora) on Strawberry in Spain.

Ellis, M. A. (2008). Phytophthora root and crown rot of fruit trees. Ohio State University, Extension Fact Sheet HYG-3029-08.
Erwin, D. C. \& Ribeiro, O. K. (1996). Phytophthora Diseases Worldwide. The American Phytopathological Society. St. Paul, MN.

Espinoza, J. G., Briceño, E. X., Keith, L. M. \& Latorre, B. A. (2008). Canker and Twig Dieback of Blueberry Caused by Pestalotiopsis spp. and a Truncatella sp. in Chile. Plant Dis. 92, 1407-1414. doi:10.1094/PDIS-92-10-1407

Jeffers, S. N. \& Aldwinckle, H. S. (1986). Seasonal variation in extent and colonization of two apple rootstock by five species of Phytophthora. Plant Dis. 70, 941-945. doi:10.1094/PD-70-941

Jeffers, S. N. \& Aldwinckle, H. S. (1988). Phytophthora crown rot of apple tree, sources of inoculum of $P$. cactorum, and $P$. cambivora as primary inoculum. Phytopathology 78, 328-335. doi:10.1094/Phyto78-328 
Jeffers, S. N. \& Wilcox, W. F. (1990). Phytophthora crown, collar, and root rots, p. 43-45, In: A.L. Jones and H.S. Aldwinckle (eds.). Compendium of apple and pear diseases. Amer. Phytopathol. Soc. Press, St. Paul, Minn.

Jeffers, S. N., Aldwinckle, H. S., Burr, T. J. \& Arneson, P. A. (1981): Excised twig assay for the study of apple tree crown rot pathogens in vitro. Plant Disease, 65, 823-825. doi:10.1094/PD-65-823

Judelson, H. S. \& Blanco, F. A. (2005). The spores of Phytophthora: weapons of the plants destroyer. Nature Reviews Microbiology, 3, 47-48. doi:10.1038/nrmicro1064

Hickey, K. D. \& Yoder, K. S. (2001). Crown or Collar Rot, Phytophthora cactorum, Kearneyscille. Fruit Research and Education Center, West Virginia University.

Matheron, M. E., Young, D. J. \& Matejka, J. C. (1988). Phytophthora root and crown rot of apple trees in Arizona. Plant Dis. 72. 481-484. doi:10.1094/PD72-0481

Minter, D. W. \& Cannon, P. F. (2015). International Mycological Institute (I.M.I.) Descriptions of Fungi and Bacteria. CABI. Pp.204.

Mazzola, M. (1998). Elucidation of the microbial complex having a causal role in the development of apple replant disease in Washington. Phytopathology, 88, 930-938. doi:10.1094/PHYTO.1998.88.9.930

Mazzola, M., Granatstein, D., Elfving, D. C., Mullinix, K. \& Gu, Y. H. (2001). Cultural management of microbial community structure to enhance growth of apple in replant soils. Phytopathology, 91.

Nakova, M. B. (2003). Phytophthora root and crown rot of fruit trees in Bulgaria. Proceedings 3rd
International Plant Protection Symposium: From Ideas to Implementation, Debrecen, Hungary. pp. 196-203.

Nakova, M. (2010). Phytophthora root and crown rot on apples in Bulgaria. Pestic. Phytomed.(Belgrade), 25, 43- 50. doi:10.2298/PIF1001043N

Oliveira, H., Nascimento, T. \& Rego, M. C. (1998). Crown gall and Cylindrocarpon black-foot diseases of grapevine in Portugal. In: Proceedings of the 19th International Geisenheim Workshop on Grapevine Grafting, 2-4 July, 1998, Geisenheim, Germany, 23-34.

Teviotdale, B. L. \& Grubler, W. D. (1999). UC Pest Management Guidelines, Apple - Phytophthora root and crown rot. UC DANR Publication 3339.

Thomidis, T., Elena, K. \& Tsipouridis, C. (2002) Persistence of fungicidal activity of four fungicides applied to peach trunks to control Phytophthora crown rot. Journal of Plant Diseases and Protection, 109, 401-409.

Waterhouse, G. M. (1963). Key to the species of Phytophthora de Bary. Mycol. Pap. 92, 1-22

Waterhouse, G. M. (1970). The genus Phytophthora de Bary. Mycol. Pap. 122, 1-59.

Welsh, M. F. (2011). Studies of crown rot of apple trees. Canadian Journal of Research, 20, 457-490.

Wilcox, W. F. (1998). Phytophthora Root, Crown and Collar Rots Phytophthora spp. Fruit Focus USA,. www.phytophthoradb. org.

Wilcox, W. F. (1993). Incidence and Severity of Crown and Root Rots on Four Apple Rootstocks Following Exposure to Phytophthora Species and Waterlogging. J. Amer. Soc. Hort. Sci. 118, 63-67. 